\title{
PROCESSES AFFECTING SUSTAINABLE USE OF AGRICULTURAL LAND IN KOSOVO
}

\author{
IBRAHIM RAMADANI, VALBON BYTYQI \\ Department of Geography, Faculty of Mathematical and Natural Sciences, University of Pristina, Kosovo
}

Manuscript received: March 3, 2018

Revised version: May 28, 2018

\begin{abstract}
RAMADANI I., BYTYQI V., 2018. Processes affecting sustainable use of agricultural land in Kosovo. Quaestiones Geographicae 37(4), Bogucki Wydawnictwo Naukowe, Poznań, pp. 53-66. 3 tables, 9 figs.

AвSTRACT: Agricultural land is facing challenges due to different human activities. Accelerated urbanisation along with explosive economic growth has further worsened the shortage of agricultural land over the last two decades. Kosovo, a country with small areas suitable for agriculture is meeting challenges due to unplanned settlement extension, coal surface mining, parcelisation of properties, etc. This paper consists in an analysis of the agricultural land fund in Kosovo, in quality, production potential and food security for the population, but also the challenges facing Kosovo with this strategic resource. The article analyses three main factors that have made the biggest changes in agricultural land in Kosovo: the effects of settlement extension, coal surface mining and parcelisation in reducing the soil fund. Some of the effects have triggered significant socio-economic processes that have changed the rural environment. Other important risks of agricultural land in Kosovo are: pollution, landfills, frequent floods, etc.
\end{abstract}

KEYWORDS: agricultural land, sustainable development, urbanisation, parcelisation, degradation, Kosovo

Corresponding author: Valbon Bytyqi, Department of Geography, Faculty of Mathematical and Natural Sciences, University of Pristina, George Bush str., n.n., 10000 Pristina, Kosovo, phone: +383 44642 658, email: valbon.bytyqi@uni-pr.edu

\section{Introduction}

The urban population, like all over the world, is growing rapidly in Kosovo as well. Globally, more people live in urban areas than in rural ones, with $54 \%$ of the world's population residing in urban areas in 2014. In 1950, about $30 \%$ of the world's population was urban, and by 2050, $66 \%$ of the world's population is projected to be urban. The rural population of the world has grown slowly since 1950 and is expected to reach its peak in a few years. The global rural population is now close to 3.4 billion and is expected to decline to 3.2 billion by 2050 (United Nations 2014).

Even in Kosovo, the urban population has grown enormously in the last five decades. Until the 1960s the changes were small because of spatial and social mobility of the population, small concentration, underdevelopment of cities and the territorial extension of urban structures. After these years, significant changes occurred, both in the demographic concentration and spatial extension of cities and in all segments of life, such as housing, food, clothing, personal hygiene and so on.

In 1953, the urban population in Kosovo was $15.6 \%$, in 1981 it was $32.4 \%$, in 1991 about $36 \%$, and today it reaches $45 \%$ of the total population. While in 1948 the number of the urban population was 71,000, in 1991 it grew to 730,000. In the period 1953-1981, the urban population increased to 388,300 or $307 \%$, while in the years of $1953-1991$ it was about 600,000 or $480 \%$. Today, about $45 \%$ of Kosovo's population lives in cities, which is $8 \%$ below the world level. The housing area and its 
funds increase in villages and cities. In Kosovo's urban settlements, the number of flats grew from 21,000 in 1951 to 88,000 in 1981, and has doubled today (Kosovo Agency of Statistics 2013).

\section{Literature review}

It is known that urbanisation is dependent on a steady supply of natural resources including fresh water, fuel, land, food and all the raw materials (Hinrichsen et al., 2001; Hardoy et al., 2001). Along with rapid urbanisation and city sprawl, there are definitely drastic increases both in demands for natural resources and in the area from which these resources are drawn (O'Meara 1999). Urbanisation also leads to significant alterations of physical environment far beyond city limits, resulting in habitat loss, climatic changes, and accumulation and spread of wastes in the environment (UNFPA, 2004). Thus, in addition to expanding urbanisation in space, it is also the loss of productive land from which people derive food. Soil not only functions as an indispensable physical base providing people with most food, feed for the livestock, fibre and the biotic fuel, but also serves as a source and a sink for greenhouse gases and an integrated part of biogeochemical cycles (Bunning, Jiménez 2003). With unique pedogenetic characteristics formed by the combined effects of environmental and biological factors over geological periods, soil could be considered as a non-renewable resource in a human time perspective (Amundson et al. 2003).

In order to protect land from uncontrolled extension of settlements and urban infrastructures, in the concept of sustainable development, it is necessary to create a zoning system or define future development. "Zoning is a system that regulates the type and intensity of land use development that occurs within a community. To create a zoning system, a local government divides the municipality into districts and regulates the construction and use of buildings within it. Regulations may differ among the districts, but within each individual district, the regulations must be uniform. A zoning system enables the community to conform its future growth to a set of goals and policies that reflect the community's vision for itself. For example, a municipality that sets a goal to strengthen the central business district would likely create a zone in its downtown into which only such intensive commercial uses would be allowed. Similarly, a community that chooses to remain rural might create a zone that allows minimal development, and then place a significant proportion of its land within this zone. Agricultural zoning is a specialized form of zoning used by communities that seek to preserve their agricultural base. It reflects a community-wide policy that farmland is a valuable resource that should be preserved to ensure the continued production of agricultural commodities. The purpose of agricultural zoning is to protect farmland from incompatible uses, which would adversely affect the long-term economic viability of the area within the region" (Kruft 2001).

Urbanisation leads to the conversion of a natural landscape to an urban area and intensifies the competition between different land-use practices in space and time presenting direct and indirect types of influence on soil resources and food security (Ramadani 2013). In addition to the impact on construction, the agricultural land fund is reduced by coal surface exploitation and coal combustion for energy production, where significant areas of productive soils are degraded by pollution (Bytyqi, Ramadani 2018).

\section{Data and methods}

On the basis of the population number and the total fund of agricultural land, land parcelisation, land productivity category, agro-technology level and possible risks that threaten the development of agriculture, we can obtain significant results for the agricultural production potential and opportunities for supplying Kosovo's population with food. The main research question is: how do the extension of settlements, parcelisation, and coal surface mining in Kosovo affect sustainable agricultural land use? To analyse the situation, data from the last century (population, agriculture statistics) were used, but mostly from the years 2010-2015. For later years there are no publications. Different maps were used during the analysis as well as aerial images to see the effects of extended infrastructure, parcelisation, and coal surface mining on the sustainable use of agricultural land in Kosovo. 
To achieve the aims of the study, we used GIS techniques, statistical data, soil capability maps and ancillary literature. Some data were collected by municipalities. By conducting case studies, using aerial images and maps, as well as our calculations, always in the context of the exploitation and use of areas at the municipality level, we can conclude that in Kosovo municipalities are developing diverse anthropogenic activities that are constantly in conflict with agricultural land which is degraded and lost.

\section{Main characteristics of agriculture in Kosovo}

Kosovo lies in the western part of the Balkan Peninsula and is characterised with a high density of the population $\left(230 / \mathrm{km}^{2}\right)$ and a high rate of small settlements (in total 1,469 settlements), while agricultural areas per capita are small compared to the EU level (Ramadani 2004).

Nearly $63 \%$ of the area lies $700 \mathrm{~m}$ above sea level, while $37 \%$ are plains (Fig. 2). Agricultural soil is the most important resource for the development of agricultural production which shares $10.5 \%$ of Gross Domestic Product (GDP) in 2016, with a decline of $2.2 \%$ compared with the year 2008 (Table 1). The agricultural sector is a leading

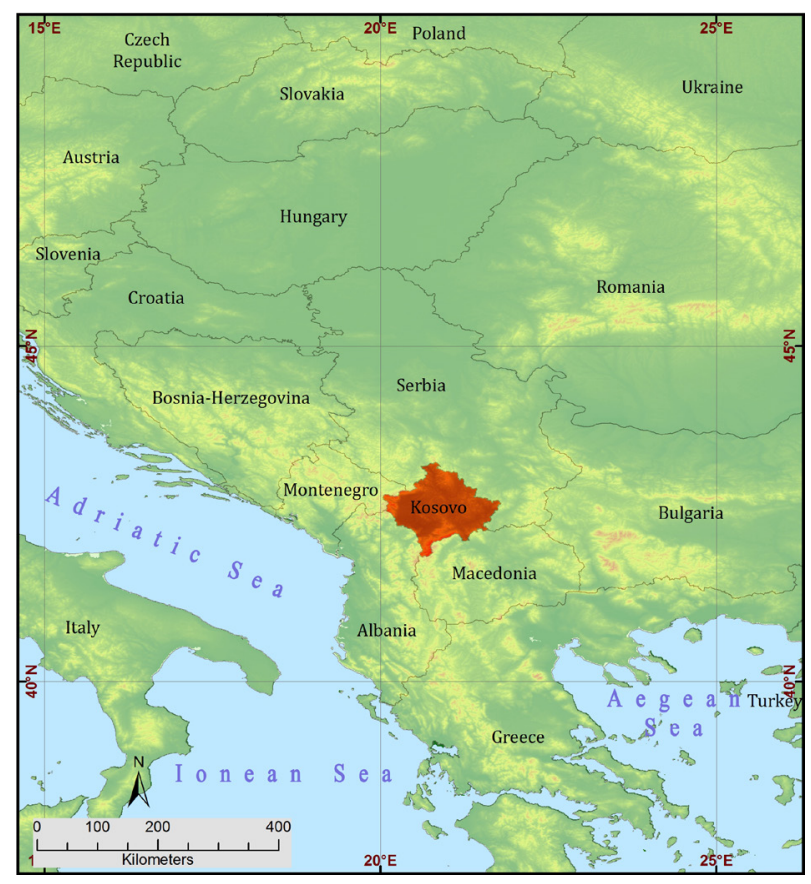

Fig. 1. Geographic position of Kosovo. Source: V. Bytyqi.

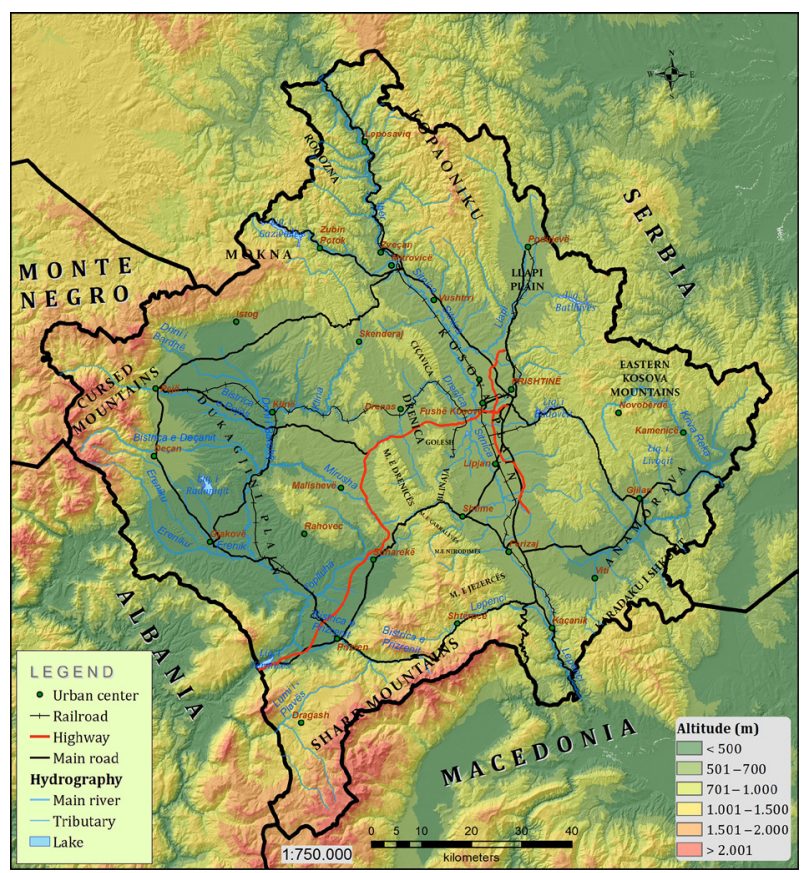

Fig. 2. Physical map of Kosovo. Source: V. Bytyqi.

contributor to the GDP (third only to wholesale and retail trade, and manufacturing). The country remains one of the poorest in Europe and is highly dependent on external support. Unemployment in Kosovo exceeds $40 \%$, and remittances from abroad constituted more than $12 \%$ of the GDP in 2012. The economy is therefore geared far more to demand than production. The agricultural sector largely embraces subsistence farming, and is characterised by small, fractured land plots, lack of technical expertise, poor transport infrastructure, irrigation, storage or processing, and lack of mechanisation. Kosovo's reliance on agriculture is a social question: agricultural activity is pervasive in Kosovo as a safety net for a large number of the population. In an economy that offers few prospects, over $40 \%$ unemployment, and a human capital drain as the able-bodied seek employment elsewhere, subsistence farming remains a primary or secondary means of livelihood for many households. The 2011 census cited a figure of $4.4 \%$ employment in agriculture, including only those formally employed. If subsistence farming is added, employment in agriculture is estimated to reach $35 \%$ of the labour force. Land ownership in Kosovo is typified by fragmented, smallscale, privately held land plots. The total number of agricultural holdings is estimated at 180,000. The average farm is $1.5 \mathrm{ha}$, often spread across 
Table 1. Share of agriculture in GDP in \% compared with some other acitivities.

\begin{tabular}{|l|r|r|r|r|r|r|r|r|r|}
\hline \multicolumn{1}{|c|}{ Year } & \multicolumn{1}{|c|}{2008} & \multicolumn{1}{|c|}{2009} & \multicolumn{1}{c|}{2010} & 2011 & 2012 & 2013 & 2014 & 2015 & 2016 \\
\hline agriculture, forestry and fishing & 12.7 & 12.6 & 14.0 & 14.1 & 12.2 & 12.0 & 11.9 & 10.3 & 10.5 \\
\hline mining and quarring & 3.1 & 2.3 & 3.1 & 2.6 & 2.3 & 2.2 & 2.1 & 2.0 & 2.1 \\
\hline manufacturing & 11.1 & 12.1 & 11.1 & 10.3 & 10.9 & 11.0 & 10.3 & 10.8 & 11.0 \\
\hline wholesale and retail trade & 11.6 & 12.5 & 12.2 & 11.1 & 12.1 & 12.3 & 12.4 & 12.3 & 12.3 \\
\hline construction & 6.6 & 6.6 & 6.4 & 7.5 & 6.7 & 6.6 & 6.0 & 6.8 & 6.5 \\
\hline transport and storage & 3.3 & 3.8 & 3.9 & 3.9 & 3.7 & 4.4 & 3.5 & 3.6 & 3.6 \\
\hline real estate acitivities & 11.0 & 10.2 & 9.5 & 8.7 & 8.6 & 8.9 & 9.0 & 8.6 & 8.0 \\
\hline others & 40.6 & 39.9 & 39.8 & 41.8 & 43.5 & 42.6 & 44.8 & 45.6 & 46.0 \\
\hline
\end{tabular}

Source: Kosovo Agency of Statistics: Gross Domestic Products 2008-2016, 2017.

an average of seven smaller plots, aggravating a farmer's ability to achieve economies of scale.

Land plots are typically held without a clear legal title or registration, and the records of properties are not properly maintained. They have either gone to urban areas or abroad. The dysfunctional and inefficient land market is a fundamental impediment to sector development not only in Kosovo but also in many other countries in the region (EFSE 2013).

Cereals, mainly wheat and corn, dominate in the structure of agricultural crops in Kosovo. The production of cereals, driven by wheat, has been gradually increasing. Corn production rose in 2015 due to an increase in livestock numbers. In 2011, the average yield of wheat, $4.6 \mathrm{t} / \mathrm{ha}$, was between the average in Eastern Europe and that of the EU, which, according to FAOSTAT, were 2.8 $\mathrm{t} /$ ha and $5.4 \mathrm{t} /$ ha respectively. The average yield of corn, $4.4 \mathrm{t} / \mathrm{ha}$, was lower than both in Eastern Europe (5.4 t/ha) and the EU (7.6 t/ha) (FAO 2012). Subsistence farming dominates the cereal sub-sector. Small farmers have a risk aversion strategy, higher transaction costs, inadequate assets to be able to access credit, and insufficient land to produce enough to make it worthwhile to enter the commercial market.

The high values of agricultural households have resulted in a high agrarian density, resulting in a great pressure on the land fund, which has been fragmented and as such has not contributed to the contemporary trends in agricultural development, as is the case in other countries in the region. The geopolitical proximity of the region has had important consequences also in the stagnation of economic development and in particular in the development of agriculture. This is also manifested in the opinion that agriculture will not survive, so many households have abandoned this activity, while the new-age labour force has started emigrating abroad to ensure existence and survival. Such a situation has caused a stagnation in agriculture, followed by other phenomena such as "social decline", land and landscape degradation.

The concern about this irreplaceable and limited resource obliges us to calculate the fund of these areas in proportion to the number of the population, the opportunities to preserve these areas of strategic importance, and the perspective of food supply. So far agricultural production in Kosovo has been mainly oriented to the cultivation of the traditional crops, namely cereals, while in the future it will be necessary to orient farming to the cultivation of crops which require more manpower, from planting to their industrial finalisation, which would result in the branching of agricultural production and its industrialisation.

Based on the data from 2010, out of Kosovo's total area of $10,905 \mathrm{~km}^{2}, 524,300$ ha or $53 \%$ is agricultural land; 460,000 ha or $41 \%$ is covered with forests, and 56,000 ha or $5.2 \%$ is non-arable land. Out of overall agricultural land, 262,098 ha or $50 \%$ is arable land and gardens, 86,000 ha or $16.4 \%$ are meadows, 9,433 ha or $1.8 \%$ are orchards and

Table 2. The structure of agricultural land by usage category.

\begin{tabular}{|l|r|r|r|r|}
\hline \multicolumn{1}{|c|}{ Year } & \multicolumn{2}{c|}{2010} & \multicolumn{2}{c|}{2015} \\
\hline Agricultural land use & $\begin{array}{c}\text { Area } \\
\text { (ha) }\end{array}$ & \multicolumn{1}{c|}{$\%$} & $\begin{array}{c}\text { Area } \\
\text { (ha) }\end{array}$ & \multicolumn{1}{c|}{$\%$} \\
\hline arable land and gardens & 262,098 & 50.0 & 183,169 & 44.8 \\
\hline orchard and vineyards & 9,433 & 1.8 & 8,909 & 2.2 \\
\hline meadows and pastures & 252,769 & 48.2 & 240,274 & 58.8 \\
\hline total & 524,300 & 100.0 & 408,559 & 100.0 \\
\hline
\end{tabular}

Source: Plani Hapësinor i Kosovës, 2010, (Spatial Plan of Kosovo) Pristina.

Statistical Yearbook of the Republic of Kosovo, 2017. 
vineyards, and 166,769 ha or $31.8 \%$ are grassland (Sharku et al. 2016). In 2015, the total area of agricultural land was reduced to 408,559 ha, which means a reduction of $5.2 \%$ compared with 2010 (Kosovo Agency of Statistics 2017). The reduction of agricultural land is mostly due to the extension of settlements, infrastructure and coal surface mining. There is a small negative trend in orchards and vineyards, where the area covers now 8,909 ha. Meadows and pastures are reduced, but they share nearly $58.8 \%$ of the total agricultural land in Kosovo (Table 2).

Despite the fact that agricultural land is limited, a lot of areas are lost year by year. In 1970 arable land and gardens were lost by 1,000 ha per year, while since 2002 circa half of the agricultural land has been left uncultivated.

Regarding the population and workforce engaged in agriculture, we drew on the latest results from the Statistical Agency of Kosovo. In 1961 , the farming population was $60.2 \%$, in 1971 it was $46 \%$, while in 1981 it declined to $18.8 \%$. Statistical data show that in the years 1961-1982 the number of active farmers rapidly declined by $302.7 \%$, while the total population of Kosovo recorded significant growth. According to the data, in 1961 an active farmer should have supplied 4.9 inhabitants with food, in 1971 it was 7.5 inhabitants and in 1981 it was 23 inhabitants. If we compare the number of active farmers to the number of members in a household, then the ratio would be $1 / 13$. Such a rapid decline in the number of active farmers creates a disorder in agricultural production. It shows that the entire population growth is removed from the agricultural economy through an agrarian exodus, replacing labour with agricultural equipment.

Another negative occurrence in agricultural development is the number of farmers above 40 years old that reaches 64\% (Kosovo Agency of Statistics 2010). Such a decline in the agricultural workforce has influenced the phenomenon of social subsidence, even involving selling or abandoning properties and finally moving households from villages to cities. This shows us how the population is going towards cities, abandoning villages and agriculture which influences deagrarianisation in Kosovo. Considering manpower, a whole number of agricultural households as production units are expected to decrease or even become extinct due to the fact that entire agricultural areas are properties without farmers, which adversely affects agricultural production. This is one of the negative sides of deagrarianisation. On the other hand, the manpower will be replaced by agricultural equipment and other tools, but how successful is this going to be when we know that the agricultural areas are divided into small properties? This will be one of the factors limiting the use of agrotechnology because agricultural machines require wider production space (Puljiz 1976). Based on this facts, we can conclude that, even though agricultural mechanisation and other agrotechnical measures in the agricultural economy have made a difference in the traditional state of production, it influenced positively the division of jobs in households. The mechanisation of agricultural households has contributed to the removal of manpower from agriculture, and it was not only positive for the transformation of households but even for the physical transformation of rural areas.

Cereals, mainly wheat and corn, dominate in the structure of agricultural crops in Kosovo. In 2015 , about 131,437 ha or $71.9 \%$ of the cultivated area was planted with these crops. From statistical data we can see that the vast majority of land is planted with cereals, while garden plants and orchards account for $9.5 \%$, and other forage crops for $15.5 \%$ (Kosovo Agency of Statistics 2017). These data show a restructuring of cultivated areas because the presented values show that in 1969 there was $87.1 \%$ of land planted with cereals, while in 2015 these areas declined to only $71.9 \%$ of agricultural land. Such a decline is in favour of other agricultural crops that give higher benefits. On the other hand, even though the area where crops are cultivated is minimised, grain yields increase its productivity, while agriculture as an important branch of the economy strives to provide more raw material for industry and to develop more intensive livestock farming. Statistical data show that agriculture is slowly developing towards vegetable and meat production, which is characteristic of contemporary societies. So, even if these changes are very slow, they are pretty hopeful. Wheat and corn take the biggest part of the land where cereals are grown. Until the 1960s, corn was the main food for the population of Kosovo, whereas now it is only used indirectly, because it is irreplaceable in increasing the yield for intensive livestock 
farming. Wheat is mainly used now to provide bread, so it is of key significance in agricultural production compared with other crops which are equally important. In addition, regardless of the scale of economic development of a region or country, crops are irreplaceable in supplying food for the population. However, they are used indirectly in developed countries, whereas in developing ones wheat is used directly. The crop production takes an important position in the country, because crop production is regarded as a regulator of economic development (Simonović 1979). Reducing the area of agricultural crops results from a decline in agricultural population, a decrease of the interest in agriculture, a low level of income accumulation, lack of investments and subsidies from the state for the development of agriculture.

Despite the decrease in crop areas, yields for a unit of cultivated area are getting bigger. This was achieved along with the general economic development when the use of agrotechnology as well as artificial fertilisers, irrigation, etc. was made possible, which enabled an increase in the total value of agricultural production and yields per hectare. Statistical data and field studies show that wheat yields per hectare increased from 2,488 $\mathrm{kg}$ in 1978 to circa 3,000 kg in 2000. However, from the calculated values we can establish that the amount of wheat per capita declined from 197 $\mathrm{kg}$ in 1969 to $156 \mathrm{~kg}$ in 1982 and $120 \mathrm{~kg}$ in 2014 as a result of rapid population growth and the abandonment of agriculture. Therefore, the rate of wheat consumption per capita within a year, which should be $150-200 \mathrm{~kg}$, indicates that wheat production does not fulfil the needs of the population of Kosovo (Pushka 1986). So, to meet the needs of the population regarding food from the crop and meat production, 100,000 tons of wheat or $35 \%$ more of the current agricultural production are needed. This amount should be added to an increase in yields per unit area, agricultural land extension, and also to the import of wheat to other countries. Despite the increase in yields per hectare, the amount of crop production per capita over the last three decades is continuously decreasing. This stagnation results from the minimisation of land parcels which does not offer any perspective, but also from youths' disinterest in agriculture, insufficient use of agrotechnical equipment, etc. Agricultural production in Kosovo is oriented mainly towards the cultivation of traditional crops, whereas in the future the orientation towards the cultivation of crops requiring more manpower in its final industrial process would be needed. It would result in branching agricultural production and the development of chain benefits (Marković 1963).

\section{Main challenges of agricultural land in Kosovo}

\section{The effects of parcelisation in agricultural land in Kosovo}

One of the main indicators that reflects the scale and intensity of agricultural development is the size of land properties. This size is one of the main factors hindering agricultural production. Large holdings intensify and increase agricultural production, while small farms have difficulties in using technology and, consequently, low yields are produced. Much effort has been made to consolidate the land and to improve the situation (Meha, Idrizi 2010; Land Consolidation Strategy 2010-2020). The structure of the property size in Kosovo is inadequate, because $61 \%$ of agricultural holdings own small holdings (up to $5 \mathrm{ha}$ ) and $38.8 \%$ of agricultural holdings have over 5 ha of property (Table 3). Such a structure of farms is the result of a high agricultural density in Kosovo. The lack of investment in the development of other sectors of the economy, its unilateral structure and an increase in the agricultural population have caused the pressure to grow on agricultural and arable land areas, shredding and reducing even more property (Ramadani 2004).

The structure of the agricultural land in terms of its size is constantly changing, which depends on a few factors such as growth in the population

Table 3. Agricultural land by size.

\begin{tabular}{|c|c|c|c|c|c|c|c|}
\hline Category in hectares & $0.1-1.0$ & $1.1-2.0$ & $2.1-3.0$ & $3.1-5.0$ & $5.1-8.0$ & $8.1-10.0$ & $>10$ \\
\hline$\%$ & 4.9 & 13.8 & 16.8 & 25.6 & 19.9 & 7.7 & 11.2 \\
\hline
\end{tabular}

Source: Kosovo Agency of Statistics, Pristina, 2010. 


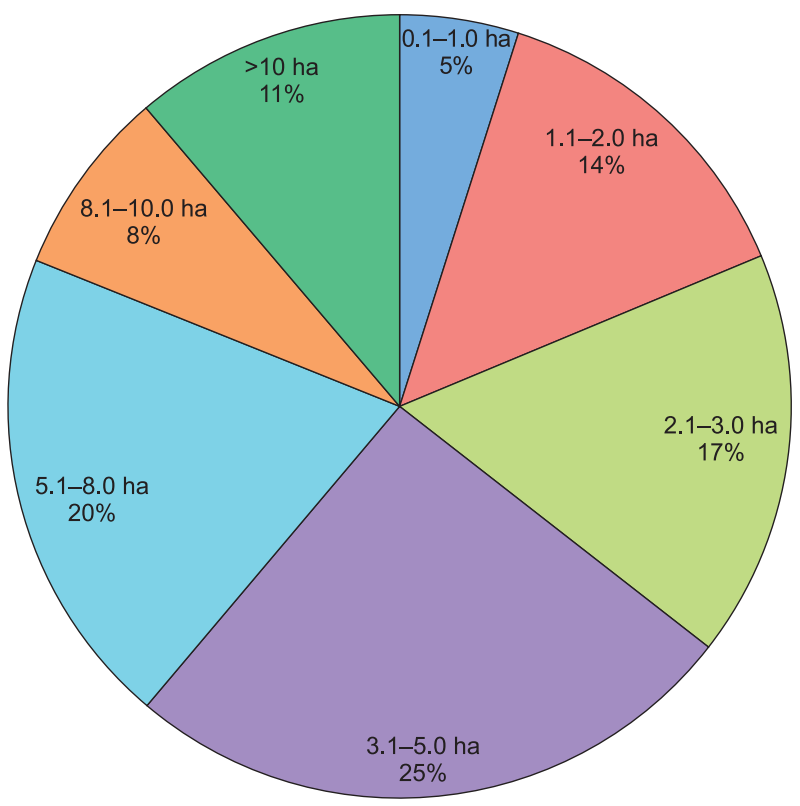

Fig. 3. Agricultural land by size.

Source: Kosovo Agency of Statistics 2010.

and in the number of households. Thus, in 1971, circa $21 \%$ of the households engaged in agriculture had farms of 5-10 ha, while in 2003 there were $13.7 \%$, which means a decrease of $7.3 \%$ in household property. The participation of a small agricultural property per household, which is 1-2 ha, is very high which means $22.2 \%$ belongs to households or $20 \%$ of the population. These data prove that in Kosovo the structure of properties whose households are engaged in agricultural process is unfavourable and this is expressed negatively in agricultural production because of obstacles to modernising and yield growth as well as the conflict between agricultural equipment and parcel boundaries (Pushka 2000).

Statistical data show that the vast part of the area belongs to individual economies, mainly concentrated around villages, divided into parcels. So, agricultural production results depend on individual manufacturers which own agricultural land. In addition, the size of the properties which depend on agricultural production is of great importance.

Bigger properties enable the development of intensive agriculture, production growth, while smaller ones deal with the problem of using agrotechnology, which is visible in their production (Pushka 1985). Unfortunately, farms in Kosovo are small and with a tendency to a further decrease and fragmentation (Fig. 4). Up to 5.0 ha are in a total of $61.1 \%$ of the properties, but with tendencies to a constant decrease.

\section{Effects of settlement extension and infrastructure in agricultural land in Kosovo}

In the context of area designation and use, of the total 38 municipalities in Kosovo, we have taken the municipality of Shtime, situated in the western part of the Kosovo Plain, as a model for

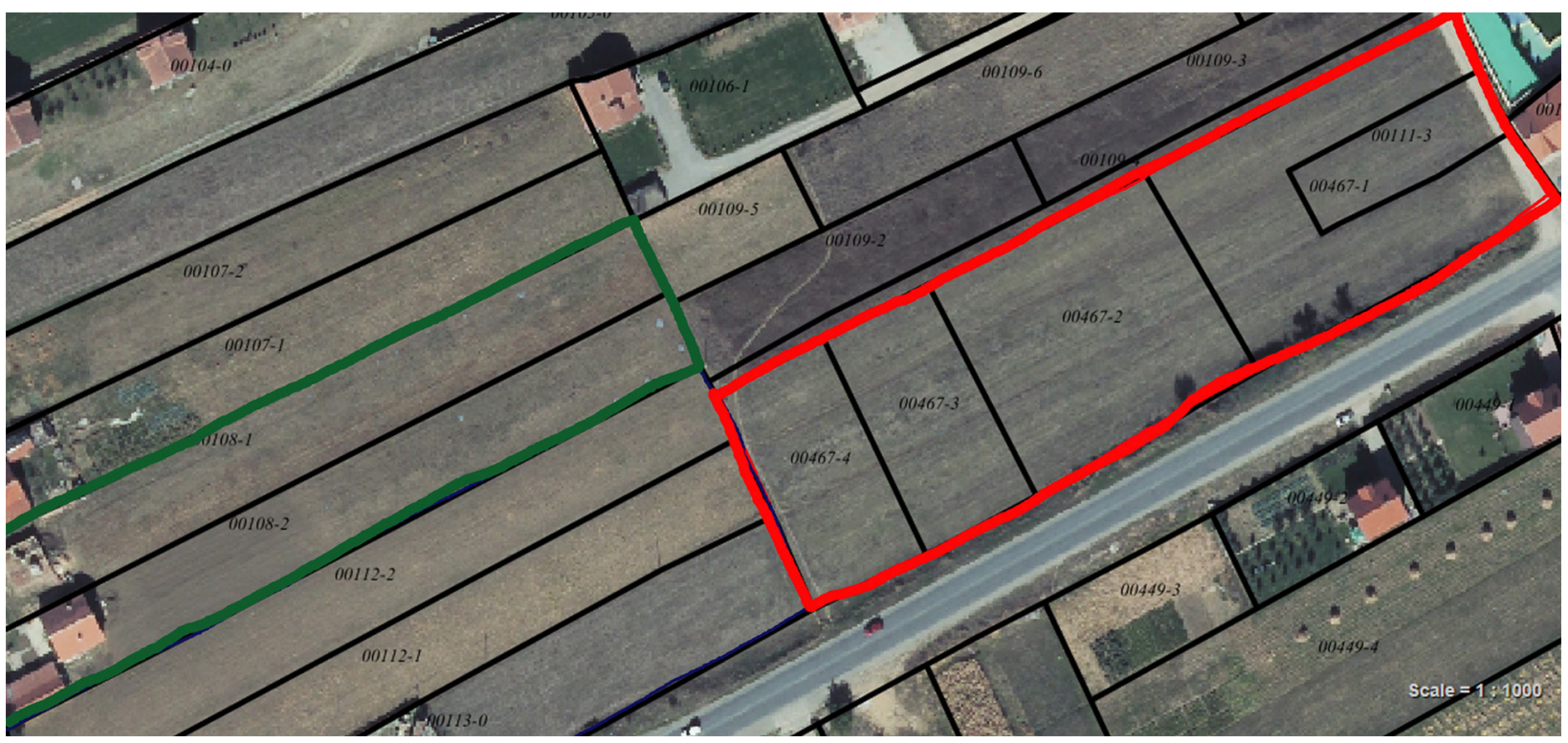

Fig. 4. Land parcelisation in Davidoc (municipality of Shtime) - red and green lines indicate former borders of land properties.

Source: Cadastral Agency of Kosova. 
the analysis of settlement and other construction development. The analyses consist in minimising conflicts between settlement extension and agricultural land. The municipality of Shtime covers the area of 13,420 ha, has 33,800 inhabitants, 23 settlements and one urban centre. A number of settlements are spread in the plain area of the municipality, including the urban centre of Shtime itself, while their extension is done in an uncontrolled way always harming high-fertility agricultural land, as well as strategically important corridors. Thus, settlements that expand into a hilly and mountainous area are characterised by a slow increase in the population or by a tendency to depopulation. The decrease in and degradation of agricultural soil caused by construction and settlement extension are a cause for concern that requires adequate treatment. Over the last two decades, the city of Shtime has covered or degraded more than 100 ha of agricultural land without counting the loss of the area by other settlement extension spread over the fields. This phenomenon will continue in the near future at a fast rate. So, by our uncontrolled actions we are losing the most important strategic resource for the future generations. Calculating the number of inhabitants in relation to high capability agricultural land of I-IV category, we may conclude that in the municipality of Shtime there are only 0.13 ha of agricultural land per inhabitant.

With regard to soil fertility, there are five categories of soil in the municipality of Shtime: 7.3\% is second-category soil, $13 \%$ is third-category, $11.4 \%$ is fourth-category, and $68 \%$ is fifth- and seventh-category. Based on this, we can conclude that the possibility of protecting arable land from construction is possible because settlements may expand into non-arable land.

Agriculture is one of the basic branches of the economy and plays an important role in the development of a region or municipality. Around $48 \%$ of the territory of Shtime municipality is agricultural land, which means that almost half of the entire municipal area is covered with wheat, i.e. $1.2 \%$ of the territory of Kosovo. (Shtime Municipality Plan 2010). According to GIS analysis, 5,609 ha are farmland, taking into account all the areas covered with wheat, meadows and gardens in settlements. During the analysis of some indicators, such as: terrain slope, situation, soil fertility, and settlement extension it turns out that Shtime municipality in characterised by three agricultural areas: mainly agricultural, agricultural and farming, and farming and forest ones. Agricultural land consisting of arable land, gardens and meadow takes a considerable wealth of arable land. This wealth has changed during the last two decades going towards harming these areas. During this period, arable land and gardens dwindled to 1,736 hectares which was the result of new buildings constructed in this area or being left as wasteland. Nevertheless, the extension of vegetable plantations has a good index that shows the development of beneficial agriculture, for which Shtime municipality has a great potential and possibility, as well as Kosovo that has favourable conditions for the development of agriculture in general.

It is worth mentioning that the land parcelisation as a negative phenomenon in the municipality of Shtime is not very different from the general level in Kosovo. The average size of land parcels is 0.62 ha. From the analysis done by GIS we understand that $73 \%$ of the parcels in Shtime municipality are 0.5 hectares in size, $17 \%$ of the parcels are $0.5-1.0$ hectares in size, approximately $7 \%$ of them are 1-2 ha in size and only 3\% are above 2 hectares. Thus, we may conclude that $90 \%$ of parcels in the municipality of Shtime have less than one hectare, which means that this is an obstacle in the development of modern agriculture (Fig. 4).

Regarding spatial planning and future development, a treatment of the erosion process is of great importance. Erosion is one of the most negative occurrences that endangers agricultural land and infrastructure, but also the weal created and planned by humans. This phenomenon, present in almost all the municipal areas in various intensity, size and forms, is accelerated mainly as a result of non-rational use of agricultural land and uncontrolled illegal logging. The areas which are exposed to medium erosion include 1,989 hectares, or $14.7 \%$ of the municipal territory. High erosion occurs in the area of 11.4 ha or $0.08 \%$, while the highest erosion covers $7.6 \%$ of the territory of Shtime municipality.

A more emphasised problem in the low area is the arable land of II-IV categories invaded by buildings and construction sites, while this area is for a high priority agricultural development purpose, thus it should be considered as an area of interest for the municipality. The map above (Fig. 

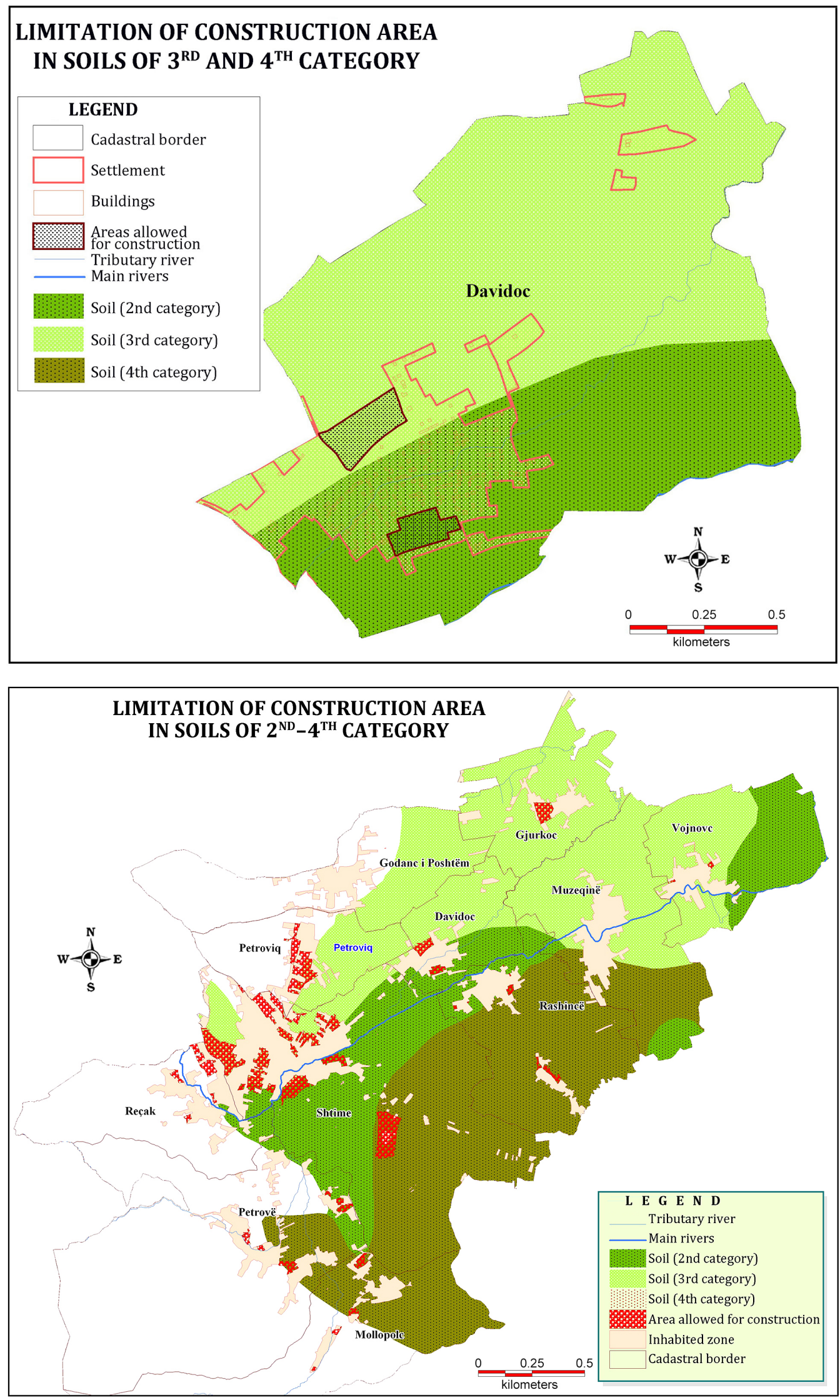

Figs 5-6. Construction sites zoning in Shtime municipality. Source: Ramadani, Shtime municipality plan. 
6) shows settlements expanded into the II-IV agricultural land category and the proposed line for their extension considering agricultural land protection. The proposed definition of construction sites minimises conflicts between the agricultural land and settlement extension. This proposal enables construction on the empty land within settlements defining ways of settlement extension towards weaker categories of land V and VI. The protection of land in the agricultural area requires a detailed research of the area: slope, type of soil, fertility, elevation, geology, etc. Taking into account the aspect of slope, biological and mechanical measures should be taken in order to stop land erosion. In arable land, where the slope is higher than $15 \%$, adequate permanent crops should be planted or afforested. Therefore, it is possible to expand settlements and construction into barren land and areas situated higher.

Soil fertility is another important factor affecting agricultural production in Kosovo. Agricultural land in Kosovo is divided into eight categories of soil fertility according to its value (Paedological map of Kosova 1983). Three first classes of fertility include arable agricultural land that is characterised by a high capability production. These areas contain 187,900 ha or $32.5 \%$ of the entire agricultural area, while the soil of the fourth category with the limited reproduction capability covers 208,000 ha or $36 \%$ of the area. The other categories of soil belong to low capability production areas. Soil of higher quality lies in the flat area, which is the most developed region in Kosovo, both in terms of agriculture and the economy in general. A relatively large concentration of the population and activities in this area makes these soils more vulnerable to degradation and loss. For their protection and sustainable management, a regional land management plan is required, which foresees the prohibition of construction of residential and infrastructural facilities, with the exception of strategic projects at the international and state level, such as the Merdare-Pristina-Durrës (Albania) Motorway and Pristina-Skopje (Macedonia).

\section{The effects of coal surface mining in agricultural land in Kosovo}

Except for settlement extension and parcelisation, the risk of degradation and loss of agricultural land in Kosovo comes from coal surface mining and energy production. Kosovo is rich in considerable resources of coal (lignite). Coal deposits in Kosovo occur in three locations: Kosovo, Dukagjini and the Drenica basin. The Kosovo Basin is located in the centre of the Kosovo Plain, in the Sitnica river valley which lies in the lowest part of the Kosovo Plain. With an area of 154 $\mathrm{km}^{2}$ (north-south of $30 \mathrm{~km}$ long, and east-west $10 \mathrm{~km}$ wide), it is one of the largest coal basins not only in the Balkans, but also in Europe. The Kosovo Basin is researched in details in terms of geological and technological aspects. In this basin are estimated 6.376 billion tons of coal reserves to all categories A $+B+C_{1}+C_{2}$ (Dushi 1996). Lignite is the most important energy resource in Kosovo, which makes up about $97 \%$ of the total electricity production. The total geological reserves of coal resources in Kosovo, evaluated according to the Institute "INKOS" are estimated to be about 12.5 billion metric tons. Power plants were built and started to operate between the years 1960-1984 and are located quite close to coal mines and also the capital city of Kosovo (Pristina) in the distance of 10 and $15 \mathrm{~km}$. Two power plants have the capacity production of 1,478 $\mathrm{MW} / \mathrm{h}$. The power plant "Kosovo A" has a capacity of $800 \mathrm{MW} / \mathrm{h}$ and "Kosovo B" a capacity of $678 \mathrm{MW} / \mathrm{h}$.

The exploitation of mineral resources leads to environmental changes. We can say that this kind of human activity is in direct confrontation with nature, it leads to major or minor changes in the environment. These changes are particularly visible when mineral resources are exploited through surface mining. In general, it causes the degradation of a wide surface area. Degrading effects can be permanent or temporary. Permanent impacts and degradation of the environment are seen through the effects that remain in the field after the end of human activities. First of all, it must be shown that permanent exploitation of useful minerals, like any exploitation, involves using non-renewable natural resources. A permanent impact changes the terrain morphology, leads to land degradation (even if theoretically resources are renewable, but in reality they are non-renewable), changes in the surface and groundwater regime as well as water flow, destruction of small ponds and native vegetation cover, the displacement of communication lines, human settlements, etc. 


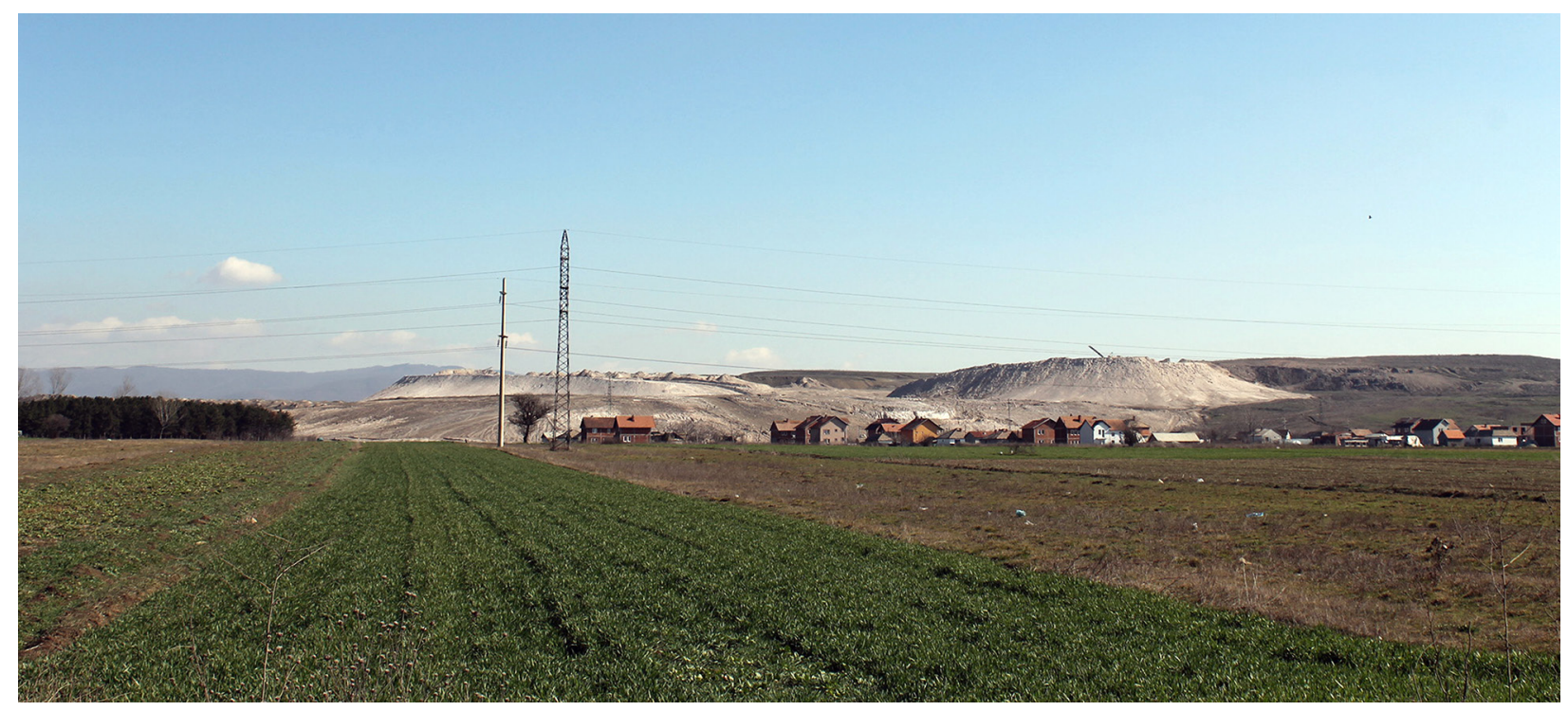

Fig. 7. Conflict between energy and agriculture. Source: V. Bytyqi.

As a result of coal exploitation drastic changes in the terrain configuration (landform) have occurred near the power plants in the Kosovo Basin creating totally degraded landscape (Bytyqi 2017).

Although Kosovo's agricultural area is significant in comparison to its size, the high density of the population, mismanagement and a growing phenomenon connected with the occupation of agricultural land with various constructions are increasingly affecting the reduction of agricultural land and weaken its quality. So far just 400,000 ha of arable land and meadows have remained, of which 70,000 ha are less useful, because they belong to VI-VIII soil category. Kosovo is currently among the countries with a smaller area of arable land per capita, a total of 0.15 ha. With the current trend in population growth, a lack of agricultural land will be increasingly expressed as a factor limiting economic development. The coal basin and power plant are located in the area with high quality agricultural land (Ramadani et al. 2011).

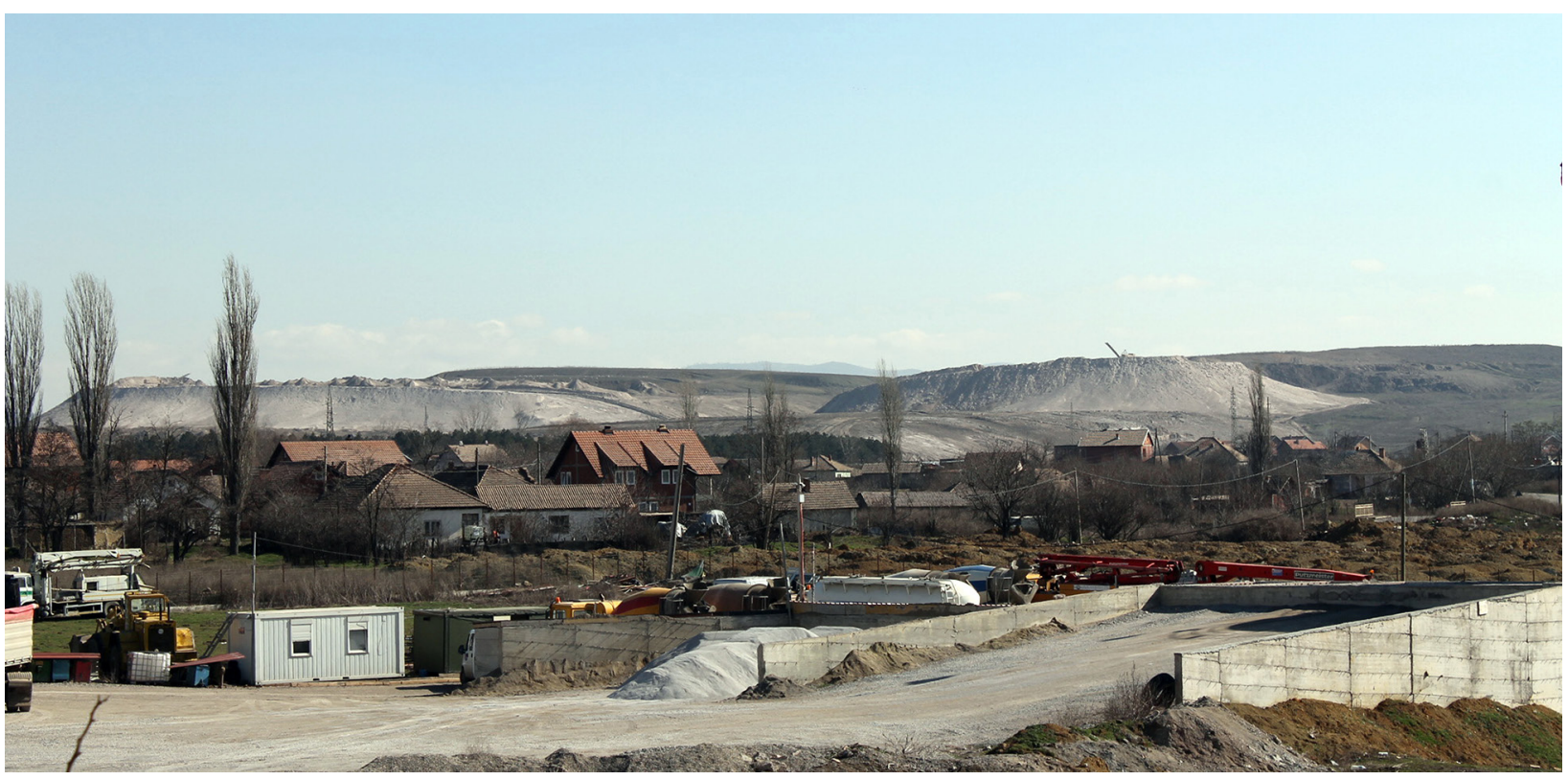

Fig. 8. Mismanagement of ash dumps. Source: V. Bytyqi. 
Coal exploitation and other processes related to electricity production appear as one of the main factors in land pollution and degradation in Kosovo. This happens because coal reserves and power plants are located in high quality agricultural areas. With the opening of surface mining on agricultural land in the settlements of Mirash, Hade, Dardhishte it is degraded through the removal of fertile layer of soil and its coverage, the disposal of ash on the fertile layers of soil, construction of power plants, transport facilities (tape), wire transmissions, supporting facilities and administrative ones (Figs 7 and 8). Thus, lands degraded by wastelands today occupy an area of about 1,559 ha while the surface that include mines about 1,470 ha. Through mining activities about 3,000 ha of agricultural land is already directly or indirectly degraded. During the years 1990-2005 they were taken directly or indirectly from wastelands, and other 600 ha of the irrigation subsystem. (Pllana 2008).

The process of electricity production in power plants is always accompanied by the emission of dust and gases such as: $\mathrm{SO}_{2}, \mathrm{NO}_{x^{\prime}} \mathrm{CO}, \mathrm{CO}_{2}, \mathrm{H}_{2} \mathrm{~S}$, ash, soot, sediments, heavy metals like $\mathrm{Zn}, \mathrm{Cu}$, $\mathrm{Cd}, \mathrm{Pb}, \mathrm{Ni}, \mathrm{Cr}, \mathrm{Fe}$, etc. (Obiliq municipality 2006).

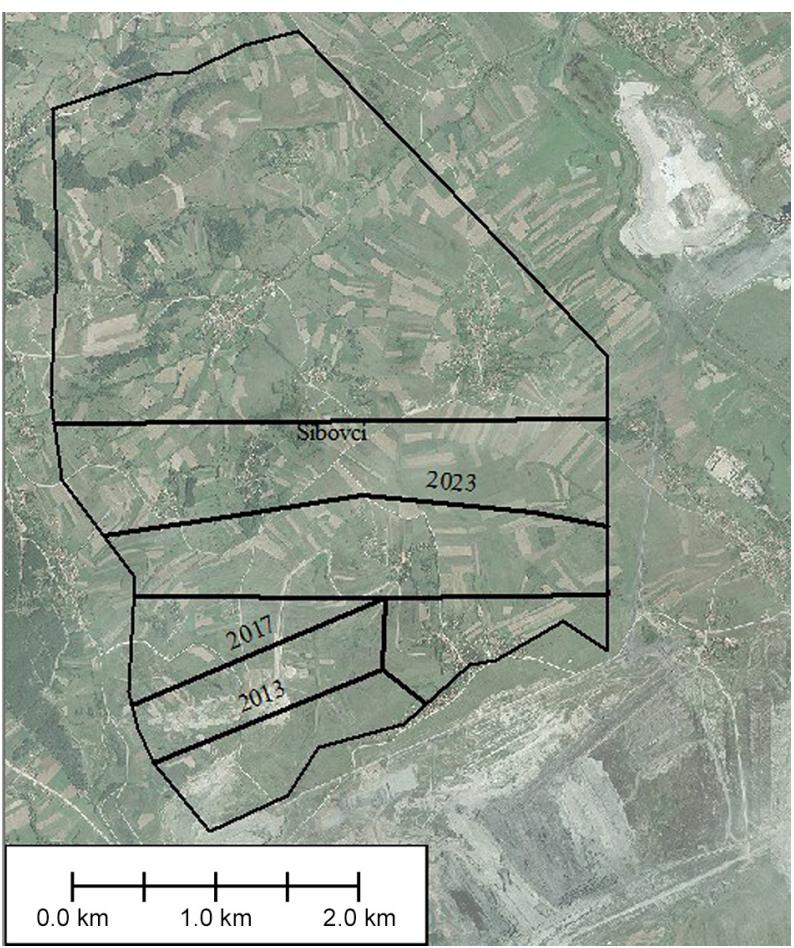

Fig. 9. The future extension of a coal mine in the Kosovo Plain.

Source: V. Bytyqi.
Emissions of these pollutants through chimneys, which are then distributed beyond the narrow impact zone, increase environmental pollution. The table below presents the results of pollutant emissions in 2003 in the industrial area of KEK (Electroenergetic Corporation of Kosovo), surveyed by INKOS (Institute for Research and Development of Kosovo).

During the energy production large quantities of ash, a major environmental pollutant, are released. With the disposal of ash a new degraded landscape is created. The total amount of ash released in 2008 for both power plants was $1,161,171$ metric tons. The total amount of ash is about 40 million metric tons, in both landfills.

\section{Conclusions}

The construction of settlement facilities, infrastructure, surface mining and landfills have influenced to a great extent the loss of agricultural land in Kosovo. There are some estimations from the past that Kosovo is losing about 1,000 hectares/ year of its farmland (Knežević, Simonović 1998). On the basis of aerial images, case studies about settlement extension, infrastructure, and coal surface mining, Kosovo is losing more than 1,000 hectares/year. By these calculations, in the past decades, more than 35,000 ha of most productive soil were gone from the agricultural land fund.

Most of the settlements in Kosovo lie in plains with high-fertility soil. People migrated from hilly-mountainous areas to plains, and the settlement extension was not properly planned. Arable land was turned into construction sites. The process of urbanisation was made through a physical extension of settlements. Land parcelisation is another factor that influences the loss of agricultural farming. The agricultural land fund in Kosovo is dominated by small properties, where farming with the use of modern agro-technology is very difficult. The application of agrotechnology in small properties will damage physical settings of the soil. Coal surface mining played an important role in the loss of agricultural land. During the utilisation of coal, there emerged a dichotomy between energy production and the agricultural land fund in the coal area.

On the basis of the high quality soil in Kosovo, which is only $32 \%$ of the total area, and the factors 
influencing the loss of the agricultural land fund in Kosovo, the share of agricultural land for each inhabitant is within the EU standards. An inhabitant of Kosovo owns only 0.37 hectare of agricultural land, and 0.15 ha of arable land, which is very unfavourable.

Settlement zoning and controlling other activities on agricultural land are necessary actions in order to preserve quality soil. To minimise the conflict between agricultural land and other actions, a zoning of business areas, construction sites and the prevention of the dispersed extension of settlements should be done. On the basis of priorities and strategic development, competent bodies at the municipal level should take the following necessary precautions: identified agricultural areas of category I-IV should be protected by law, by respecting the defining line of settlement sites; development and regulatory plans for secondary and local centres should be compiled as soon as possible; in case of a need for settlement extension, priority should be given to constructions on wasteland and low-quality agricultural land; gaps between the existing settlement border lines should be populated, which would positively affect an increase in settlement density and compactness. One of the priorities of spatial planning should be to protect quality agricultural land and prohibit constructions on the soil of I-IV categories.

\section{References}

Amundson R., Guo Y., Gong P., 2003. Soil diversity and land use in the United States. Ecosystems 6: 470-482.

Assembly of Republic of Kosovo, 2012. Law on Land Regulation. Law No.04/L-040, Pristina.

Bunning S., Jiménez J.J., 2003. Indicators and assessment of soil biodiversity/soil ecosystem functioning for farmers and governments. Paper presented at the OECD Expert Meeting on Indicators of Soil Erosion and Soil Biodiversity, Rome.

Bytyqi V., Ramadani I., 2018. Environmental changes from coal surface mining in Kosovo. Ecoforum Journal 7(2).

Bytyqi V., 2017. Kosovo Eastern Region - Physical-geographical features, natural resources and geoenviromnetal impacts. ASHAK, Pristina.

Cadastral Agency of Kosova, 2017. http://geoportal.rksgov.net/search?municipalityId=22 (accessed: 15 December 2017).

Coal Industry Advisory Board, International Energy Agency, 2006. Case studies in sustainable development in the coal industry. People, IEA Publications, Paris.

Dushi M., 1996. Lëndët minerale të Kosovës dhe mundësitë për valorizim të shumëfishtë, Konferenca: Shqyrtim multidisciplinor $i$ mundësive zhoillimore të Kosovës (Ore minerals in
Kosovo and opportunities for multiple valorisation, Conference paper), ASHAK, Pristina (in Albanian).

EFSE, 2013. Study Report, European Fund for Southeast Europe, Development Facility, Agricultural Finance in Kosovo. MDA.

Governor's Centre for Local Government Services, 2001. Local land use controls in Pennsylvania, Planning Series 1, (fourth edition), Department of Community and Economic Development. Commonwealth Keystone Building 400 North Street, Harrisburg, Pennsylvania.

Hardoy J.E., Mitlin D., Satterthwaite D., 2001. Environmental problems in an urbanizing world: Finding solutions for cities in Africa, Asia and Latin America. Earthscan Publications, London.

Hinrichsen D., Blackburn R., Robey B., Goldstein S.M., 2001. Population growth and urbanisation: Cities at the forefront. Population report (Special Session edition), Population Information Program Centre for Communication Programs. Johns Hopkins University, Baltimore, USA.

Knežević M., Simonović R., 1998. Ekološki problem Kosovske Mitrovice, Naučno istrazivački projekat (Ecological problems in Mitrovica), PMN, Pristina 58-67 (in Serbian).

Kosovo Agency of Statistics, 2017. Gross Domestic Product 2008-2006 (report). http://ask.rks-gov.net/media/3629/gdp-2008-2016.pdf (accessed: 18 May 2018).

Kosovo Agency of Statistics, 2017. Statistical Yearbook of the Republic of Kosovo (report), http://ask.rks-gov.net/en/ kosovo-agency-of-statistics/add-news/statistical-yearbook-of-the-republic-of-kosovo-for-2017 (accessed: 18 May 2018).

Kosovo Agency of Statistics, 2013. Kosovo Census Atlas, Pristina.

Kruft D., 2001. Agricultural zoning. The Dickinson School of Law of the Pennsylvania State University.

Marković P., 1963. Strukturne promene naselu, kao rezultat ekonomsko grazvitka (Structural changes in villages as a result of economic development), Zadružna Knjiga, Beograd (in Serbian).

Meha M., Idrizi B., 2010. Analyses of development models of land consolidation in Kosovo and its perspectives. Journal of Agricultural Extension and Rural Development 2(6): 97-105.

Ministry of Agriculture, Forestry and Rural Development, 2010. Land Consolidation Strategy 2010 - 2020, Pristina.

Ministry of Environment and Spatial Planning, 2010. Kosovo Spatial Plan 2010-2020 (in Albanian), Pristina.

Ministry of Environment and Spatial Planning, 2017. State of the Environment in Kosovo (report). http:/ / www.ammk-rks.net/repository/docs/Raporti_i_mjedisit_2016_ web_format_eng_22817.pdf (accessed: 7 March 2018).

Montgomery C., 2006. Environmental Geology (seventh edition), McGraw-Hill, Boston.

Municipal Assembly of Obiliq, 2006. Spatial analysis (in Albanian). Obiliq, Kosovo.

Municipal Assembly of Shtime, 2010. Municipality development plan of Shtime 2010-2020, Kosovo.

O'Meara M., 1999. Reinventing cities for people and the planet. Worldwatch Paper 147. Worldwatch Institute. Washington, DC.

Paedological map of Kosova, 1983. Institute for Hydroeconomy, Beograd.

Pllana R., 2008. The use of natural resources and geoenvironmental impacts (in Albanian). Scientific round table: The environment of Kosova - Resources and human factor, ASHAK, Pristina. 
Puljiz V., 1976. Proces deagrarizacije stanovništva u Jugoslaviji, Geografski aspect društveno-gospodarsko grazvitka SFR Jugoslavije I svijeta (Deagrarianisation process of population in Yugoslavia. Geographical aspect of social-economic development), Školska Knjiga, Zagreb (in Croatian).

Pushka A., 1985. Some socio-economic aspect of population and agricultural households according to size of properties in Kosovo (in Albanian). Përparimi 3: 156-168.

Pushka A., 1986. Trend of some socio-economic parameters in Kosovo (in Albanian). Geographical Research 7: 115-122.

Pushka A., 2000. Agricultural geography. Alb-Shtanc, Pristina.

Ramadani I., 2000. The effects of coal surface mining in living environment in Pristina (in Albanian). Studime gjeografike 12, QSGJ. Tirana: 99-107.

Ramadani I., 2004. Rural development (in Albanian). Dukagjini, Peja: 131-145.

Ramadani I., 2013. Natural resources management. Vatra, Pristina.

Ramadani I., Gashi G., Ejupi A., Bytyqi V., 2011. The environment impacts of power plants in Kosovo and sustainable development, Journal of International Environmental Application \& Science 6(3): 332-338. http://www.jieas. com/volumes/vol111-3/abs11-v6-i3-5.pdf (accessed: 22 December 2017).
Sharku A., Tahirsylaj S., Shala I., 2016. Status of soil, climate and digital mapping information in Kosovo, 1st Interim Meeting of the Regional Expert Advisory Working Group on Development, Mapping and Analyses of Areas with Natural Constraints 30 June - 1 July, Andrevlje.

Simonović D., 1979. Samo upravna tranformacija poljoprivrede (Socio-economic transformation of agrictulture). Savrenena Administracija, Beograd (in Serbian).

The Aluminium Industry's Sustainable Development Report, 2001. International Aluminium Institute, London, Associations and Int. Org/UNEP, Report date 20.11.01. CPC and EE\&LCI/LCA, London.

The European Union's IPA Programme for Kosovo, Agricultural Land Pollution Survey (ALPS) in Kosovo (2010), CRIS Number: 2013/313-408, European Union Project by GIZ IS (DE) and NIRAS (PL). Final Report from March 18th 2013 - March 17th 2015.

UNFPA, 2004. State of World Population 2004: The Cairo consensus at ten: Population, reproductive health and the global effort to end poverty. Chapter 4. Migration and urbanisation. United Nations Population Fund, New York.

United Nations, 2014. World Urbanisation Prospects (the 2014 revision). Population Division, Department of Economic and Social Affairs. UN, New York. 